\title{
SEMIOTIC ANALYSIS OF IDIOMATIC IN THE MAZE RUNNER: THE DEATH CURE MOVIE
}

\author{
$1^{\text {st }}$ Anisa Alawiyyah \\ English Education Program \\ STKIP Bina Mutiara Sukabumi, Indonesia \\ nisaalawi@gmail.com \\ $2^{\text {nd }}$ Ria Saparianingsih \\ English Education Program \\ STKIP Bina Mutiara Sukabumi, Indonesia \\ saparia2904@gmail.com \\ $3^{\text {th }}$ Nadia Nurul Maulidiyah \\ English Education Program \\ STKIP Bina Mutiara Sukabumi, Indonesia \\ nadianurulm26@gmail.com
}

\begin{abstract}
This research discussed the semiotic analysis of idiomatic expressions found in The Maze Runner: The Death Cure movie by Wess Ball and its impact on English. This research aimed to find idiomatic expressions revealed in the dialogue in the movie; to find the meaning of symbols contained idiomatic expressions in dialogues; to find the impact of semiotic analysis in idiomatic expressions found in movie. In this research, researchers used qualitative research in the type of content analysis using descriptive approach to help the analysis of the data that found in the movie. The researchers looked for idiomatic expressions in the movie and symbols of idiomatic expressions. Finally, researchers reveal the impact of semiotic analysis in idioms found in movie on English. From the results, there are 59 idiom expressions divided into lexemic and sememic idioms. From lexemic idiom found 37 phrasal verbs; 2 irreversible binomials; 10 phrasal compounds; and 1 incorporating verb. From the sememic idiom found 2 idioms of politeness; 1 idiom of detachment; 4 idioms of greeting; and 2 famous quotations idioms. There are 26 symbols from 59 idiom expression in the movie. Its effects on English make students more fluent in English and look like native speakers, add new vocabulary, make students aware of cultural differences in language, and know more about meaning.
\end{abstract}

Keywords: Idiomatic expression; semiotic analysis; implication; movie; English language skill

\section{INTRODUCTION}

Communication is the act of conveying data for the reason for creating a shared understanding. It is something that humans do daily in a social interaction process. In other words, communication is the past time of conveying information through the alternate of thoughts, messages, or statistics, as via speech, visuals, signals, writing, or behavior, creating, exchanging, sharing ideas and experiences between sender and receiver (Abuarqoub, 2019).

The receivers may additionally not (fully) recognize the language utilized by the transmitter. This could arise if the transmitter's language is received to the receiver. There may be language problems (that the communication process) if the message includes technical statistics and also the receiver's is not at home with the technical phrases used. Cultural differences created via somebody's history and reveal an impact on their belief of the globe. Such cultural variations may additionally have an impact on the interpretation (decoding) of the message sent (Spolsky, 1995). Every country and region have special languages and cultures. Therefore, once people 
communicate with others, people don't seem to be only mastering the language however also conclude about the culture. It appears while the scholars analyze the proverb, saying and idioms.

An idiom is a unit of words or phrases whose meaning cannot be determined by literal definition of the phrase itself (Purnamasari, 2009). That means of idiom cannot be determined word to word. For example, the phrase "closedown" means bankrupt, it is mean not "close" because of this near a window or something and "down" which means that pass down.

An important part of an idiom is that these figurative expressions make a language greater vibrant. They are helpful while language adorning or when looking for a new way of expressing oneself. Idiomatic Expressions or idiom should be understood by non-native speaker, because idioms are used by native speaker in their daily life. By learning idiomatic expressions, it can help non-native speakers of an English language become more fluent, sounds more like native speakers, and leads to be a better understanding of the culture and customs of that particular language. (Thyab, 2016).

Furthermore, idiomatic expressions are found to be culture- based those idiomatic expressions carry within them the history, heritage, culture and customs of its native users (Rizq, 2015). so, it can be said that idioms are derived from physical human experiences.

Idioms that are based on physical human experiences, such as anger being associated with heat are easier to recognize and understand by non- natives. Due to the strong similarities across different cultures in basic physical experiences, such as being sick or well, hot or cold, idioms that are derived from such images are often the same and fairly easy to understand (Boers, 2008).

However, idioms that are derived from specific domains are usually different across cultures, because these domains are not equally important across cultures. For example, many idiomatic expressions in the English language are derived from sailing because of England's history as a seafaring country and has the idioms such as "neck and neck" meaning "it's hard to say who will win"; "win hands down" meaning "to win easily"; and "go off the rails" meaning "to go wrong or out of control". these tree idioms are derived from horse racing due to the popularity of horse racing as a sport in England. (Ibid).

Idioms are utilized in many approaches in language, including through movies where speakers must bring messages which can best be spoken with idiomatic expression. The movie is one of some highquality media for mastering the English language. Through watching a movie, the students can know the applying of English language on day-by-day activities like what is shown inside the movie.

Therefore, the students can recognize the messages that convey from the movie at constant time as we have got been analyzed it approximately.

The researchers is intended to analyse the meaning of idiomatic expressions found on the dialogue spoken by using the characters of The Maze Runner: The Death Cure by Wess Ball particularly idiomatic expression which contains symbol through a semiotic principle of Roland Barthes. From this analysis, the result from the denotative that means the super signification and the connotative meaning as the second rate of the signification and also the myth of the image in idiomatic expression as the inner most layer of image and meaning. This study also focuses on finding the implication of idiomatic expression and semiotic analysis in English language skills.

Every language in around the world has its very own idiom. According to Gairns \& Redman (2011), idioms are usually described as corporations of words that is not like the person words. Example, "beneath the weather" has not anything to do with the literal meaning of 'the weather', it means feeling ill.

As those examples illustrate, idioms can be almost impossible to bet out of context, while others are greater transparent. Idioms are particularly common in spoken English. Some people prefer to apprehend an 
idiom, but they will need to learn a lot of them as constant phrases.

Finding the meaning of idiomatic expressions may not be as easy as one might think. For instance, the meaning of an idiomatic expressions is not always included in the dictionary. It may give the non-native speaker the literal meaning of the words composing an idiomatic expression. That ideally, idioms shouldn't be learned in an instant way, this especially is true idioms (Ambrose, 2003). Movies, magazines, newspapers, television shows, radio programs are also source of idioms that can help students and non-native speaker to expand their knowledge and use idioms in their daily life.

An idiom may be a phrase which implies one thing totally different from the separate words that area unit a part of it. Each language has its own idiomatic way of expressing that means thru lexical object consisting of phrases or phrases. All languages have idioms significantly land language that's moneyed in vocabulary, moreover as idiomatic expressions (Palmer, 1976).

An idiom also implies metaphors, secondary meaning, and figurative language. (Cowie et al., 1983). Idiomatic expression also incorporates symbols by using a semiotic method. Semiotic is the technological of symbols. This technological considers that the social and cultural phenomenon could be a symbol.

A symbol is a concept of varying meaning and changing value, in the historical horizon of distinguishing between sign and symbol at the same time means that the symbol obtains a deeper sense from something invariable (Todorov, 1984).

Barthes became a parent so synonymous with the take a glance at of semiotics. (Barthes, 1968) concept that the operational concept is understood because the order of signification. In simple terms, Barthes 's semiotic take glance at is defined into two kind which are denotative and connotative.

Denotative is the actual meaning, or a phenomenon that seems to the senses, or it is called a primary description. While connotative is the cultural meanings that emerge or it should be stated as a significance that arise cause cultural construction, so there is a shift, however still be connected to the symbol or the mark.

Knowledge of idioms is very important to nonnative speakers' understanding of the language that native speakers merely use (Ovando and Collier, 1985). Thus, the use of idiom is essential part to learn English. Besides, the students have to learn semiotic which can make students more meaningful, more understand and misunderstanding would not be happened. Idiom and semiotic has the implication to daily activity especially on English language skills.

In this research are aimed to find idiomatic expressions revealed in the dialogue in the movie; to find the meaning of symbols contained idiomatic expressions in dialogues; and to find the impact of semiotic analysis in idiomatic expressions found in the movie.

\section{METHOD}

In this research, researchers used qualitative research. Qualitative research is used to collecting data, analysis data, and interpretation of complete narrative and visual (e.g., non numerical) records to advantage insights into a selected phenomenon of interest.

Qualitative research techniques are primarily based on specific beliefs and are designed for distinctive purposes than quantitative research techniques (Gay, Mills, and Airasian, 2012). For example, in qualitative researchers do not continuously receive the read of a stable, coherent, uniform world.

The researchers as the main instrument use record have a look at as the technique of collecting data that are the idiomatic expressions revealed on the dialogue spoken by the characters of The Maze Runner: The Death Cure movie by Wess Ball. The researchers collected the data as follows watching a movie, reading a subtitle script in English and Indonesian, 
comparing a subtitle script in English and Indonesian, classified the idiomatic expressions and express the meaning of its (Makkai, 1972). After did collecting the data, the researchers also analysis data, based on Merriam (1998) technique that discussed by Polit and Beck (2014), they are narrative, coding, interpretation, confirmation, and presentation.

Based on that theory, the researchers take some steps to analyze data, such as: First, collect data by watching the movie and reading a whole subtitle script of The Maze Runner movie. Second, compare two subtitles script in English and Indonesian to find out the idiomatic expressions in the dialogue spoken by the characters of The Maze Runner: The Death Cure movie. Third, classified the idiomatic expressions and express the meaning of the idiomatic expressions. The last, describe in detail the idiomatic expressions have been found related to the theoretical framework and relevant studies.

\section{RESULT AND DISCUSSION}

The Idiomatic Expressions Revealed in the Dialogue Spoken by the Characters of The Maze Runner: The Death Cure Movie.

There are 59 idiomatic expressions based on Makkai's classification of idiom. Makkai classifies idioms into Lexemic and Sememic idioms. In his classification of idioms, Makkai (1972) still classifies the lexemic and sememic idiom into various subcategories.

\begin{tabular}{|c|c|c|c|}
\hline No & $\begin{array}{c}\text { Kind of Idiomatic } \\
\text { Expression }\end{array}$ & number & $\begin{array}{c}\text { relative } \\
(\%)\end{array}$ \\
\hline 1. & Phrasal Verb & 37 & 62,7 \\
\hline 2. & Irreversible Binominal & 2 & 3,4 \\
\hline 3. & Phrasal Compound & 10 & 16,9 \\
\hline 4. & Incorporating Verb & 1 & 1,7 \\
\hline 5. & $\begin{array}{l}\text { Idioms } \\
\text { Institutionalized } \\
\text { Politeness }\end{array}$ & 2 & 3,4 \\
\hline 6. & $\begin{array}{l}\text { Idioms } \\
\text { Institutionalized } \\
\text { Detachment } \\
\text { Indirectness }\end{array}$ & 1 & 1,7 \\
\hline 7. & $\begin{array}{l}\text { Idioms } \\
\text { Institutionalized } \\
\text { Greeting }\end{array}$ & 4 & 6,8 \\
\hline 8. & Familiar Quotations as Idioms & 2 & 3,4 \\
\hline & Total & 59 & 100 \\
\hline
\end{tabular}

There are found 50 idioms in the subcategories of lexemic categories that are:

\section{Phrasal Verb}

There are found 37 idioms in phrasal verbs, and there are some of them with the same idiomatic expression but in different duration, for example:

\begin{tabular}{|c|c|c|c|c|}
\hline \multicolumn{5}{|c|}{ Table 2. Phrasal Verb } \\
\hline $\begin{array}{c}\text { Dialogue using } \\
\text { Idiomatic Expression }\end{array}$ & Duration & \begin{tabular}{|l|} 
Idiomatic \\
Expression \\
\end{tabular} & $\begin{array}{c}\text { Kinds of Idiomatic } \\
\text { Expression }\end{array}$ & Meaning \\
\hline $\begin{array}{l}\text { Ava: It's promising. But } \\
\text { we'll need a larger } \\
\text { sample to work with. } \\
\text { The Professor: All } \\
\text { right. Carry on. }\end{array}$ & $\begin{array}{l}00: 24: 00,760- \\
00: 24: 10,695\end{array}$ & Carry on & Phrasal verb & $\begin{array}{l}\text { To keep doing a } \\
\text { before, continue }\end{array}$ \\
\hline
\end{tabular}

In this dialogue, there is idiomatic expression "Carry on" with the structures, "Carry" is a verb and "on" is an adverb that follows the verb "carry" in these idiomatic expressions. From the context of the dialogue, the meaning of this idiom is "to keep doing as before, continue". So, from the dialogue said by Character Ava and Professor, It's promising. But we'll need a larger sample, it can be seen that Ava tried to explain to others characters that we need to continue collecting the sample to create the cure for human society. The word "Carry on" has strong meaning and urged people to do something as soon as possible. The idiom is belonging to Phrasal verb because the idioms contained the combinations between verb and preposition or adverb that formed new meaning of the idiomatic. (Makkai, Boatner, and Gates, 2004).

\section{Irreversible Binomial}

There are found 2 idioms in irreversible binomial, for example:

\begin{tabular}{|c|c|c|c|c|}
\hline $\begin{array}{c}\text { Dialogue using } \\
\text { Idiomatic Expression }\end{array}$ & Duration & $\begin{array}{l}\text { Idiomatic } \\
\text { Expression }\end{array}$ & \begin{tabular}{|c|} 
Kinds of \\
Idiomatic \\
Expression
\end{tabular} & Meaning \\
\hline $\begin{array}{c}\begin{array}{c}\text { Thomas: I don't think } \\
\text { we have much of a } \\
\text { choice. }\end{array} \\
\text { Newt: All right. I get } \\
\text { shotgun. } \\
\text { Frypan: Well, here we } \\
\text { go. } \\
\text { Newt: Yeah, just take it } \\
\text { nice and slow. }\end{array}$ & $\begin{array}{l}00: 25: 56,040-->> \\
00: 27: 04,374\end{array}$ & Nice and slow & $\begin{array}{c}\text { Irreversible } \\
\text { binomial }\end{array}$ & $\begin{array}{l}\text { To go or act } \\
\text { slowly, } \\
\text { carefully, } \\
\text { and gently. }\end{array}$ \\
\hline
\end{tabular}

In this dialogue, there are found idiomatic expression "Nice and slow" with the structures, "Nice" is an adjective and "slow" is an adjective, which are separated by "and" is a conjunction in these idiomatic 
expressions. From the context of those dialogue, the meaning of this idiom is "to go or act slowly, carefully, and gently". as the dialogue said by Character Newt in the movie, Yeah, just take it nice and slow. It can be shown that Newt urge George, Frypan, and Thomas finish the mission slowly without rush and finish it well. In linguistic terms, the idiom "nice and slow" refers to irreversible binomial because the words used together in fixed order as an idiomatic expression or collocation, and the verbs cannot be reversed. (Farlex, 2019).

\section{Phrasal Compound}

There are found 10 idioms in phrasal compound, and there are some of them with the same idiomatic expression but in different duration, for example:

\begin{tabular}{|c|c|c|c|c|}
\hline $\begin{array}{l}\text { Dialogue using } \\
\text { Idiomatic } \\
\text { Expression }\end{array}$ & Duration & $\begin{array}{l}\text { Idiomatic } \\
\text { Expression }\end{array}$ & $\begin{array}{l}\text { Kinds of } \\
\text { Idiomatic } \\
\text { Expression }\end{array}$ & Meaning \\
\hline $\begin{array}{l}\text { Thomas: Hey, } \\
\text { Brenda, you got } \\
\text { company! } \\
\text { Brenda: Go, } \\
\text { go, go! } \\
\text { The company: } \\
\text { Open fire. } \\
\text { George: Watch } \\
\text { out! Holy shit! }\end{array}$ & $\begin{array}{r}\bullet 00: 04: 52,360 \text {--> } \\
00: 05: 16,450 \\
\bullet 01: 39: 31,800 \quad->> \\
01: 39: 33,857 \\
\bullet 01: 39: 31,800 \quad->> \\
01: 39: 33,857\end{array}$ & Open fire & $\begin{array}{l}\text { Phrasal } \\
\text { compound }\end{array}$ & $\begin{array}{l}\text { To begin } \\
\text { shooting at } \\
\text { someone or } \\
\text { something. }\end{array}$ \\
\hline
\end{tabular}

In this dialogue, there is found idiomatic expression "Open fire" with the structures, "Open" is a verb and "fire" is a noun which is a compound nouns in these idiomatic expressions. From the context, the meaning of this idiom is "to begin shooting at someone or something". from the dialogue said by The Company "Open fire", has strong meaning that "fire" means "shoot" directly to the enemy by lots of people including Brenda, Thomas, and George in the movie. The idiom "Open Fire" is belonging to Phrasal Compound because the use of two words between open and fire formed a single thought. The function of the word is verb and noun. These compounds can be challenging for non-native English speakers because they are often idiomatic. (Spears, 2006).

\section{Incorporating Verb}

There is found only one idiom in incorporating verb, for example:

\begin{tabular}{|c|c|c|c|c|}
\hline & \multicolumn{4}{|c|}{ Table 5. Incorporating Verb } \\
\hline $\begin{array}{l}\text { Dialogue using } \\
\text { Idiomatic } \\
\text { Expression }\end{array}$ & Duration & $\begin{array}{l}\text { Idiomatic } \\
\text { Expression }\end{array}$ & \begin{tabular}{|c|} 
Kinds of \\
Idiomatic \\
Expression
\end{tabular} & Meaning \\
\hline $\begin{array}{l}\text { Minho: You } \\
\text { sure about this? } \\
\text { Thomas: Not } \\
\text { really. } \\
\text { Minho: Nice } \\
\text { pep talk. } \\
\text { Newt: Yeah, } \\
\text { we're all } \\
\text { bloody inspired. }\end{array}$ & $\begin{array}{l}01: 28: 04,160 \quad \cdots> \\
01: 28: 11,651\end{array}$ & Pep talk & $\begin{array}{l}\text { Incorporating } \\
\text { verb }\end{array}$ & $\begin{array}{l}\text { A speech that } \\
\text { makes people feel } \\
\text { good so they will } \\
\text { try harder and not } \\
\text { give up. }\end{array}$ \\
\hline
\end{tabular}

In this dialogue, there is found idiomatic expression "Pep talk" with the structures, "Pep" is a noun and "talk" is a verb which is a compound verb in these idiomatic expressions. From the context, the meaning of this idiom is "makes people feel good so they will try harder and not give up". from the dialogue said by character Minho, Nice pep talk. It is shown that Minho spoke enthusiastically to Newt that he made Newt happy and feels good and they would try harder to made revenge to the enemy and not give up. The idiom belongs to Incorporating verb because the verb combines thoroughly and form an indistinguishable whole in words and become a compound verb. (Makkai, Boatner, \& Gates, 2004).

There are also found 9 idioms in the subcategories of sememic categories, that are:

Idioms of Institutionalized Politeness There are found 2 idioms in idioms of institutionalized politeness, for example:

\begin{tabular}{|c|c|c|c|c|}
\hline \multicolumn{5}{|c|}{ Table 6. Idioms of Institutionalized Politeness } \\
\hline $\begin{array}{l}\text { Dialogue using } \\
\text { Idiomatic } \\
\text { Expression }\end{array}$ & Duration & $\begin{array}{l}\text { Idiomatic } \\
\text { Expression }\end{array}$ & $\begin{array}{l}\text { Kinds of Idiomatic } \\
\text { Expression }\end{array}$ & Meaning \\
\hline $\begin{array}{l}\text { Brenda: May I help } \\
\text { you? } \\
\text { George: It looks good. } \\
\text { How you feeling? } \\
\text { Brenda: Awesome. } \\
\text { Geoge I I was just } \\
\text { asking. }\end{array}$ & $\begin{array}{l}00: 13: 51,920 \quad \cdots \\
00: 13: 59,536\end{array}$ & $\begin{array}{l}\text { May I help } \\
\text { you? }\end{array}$ & $\begin{array}{l}\text { Idioms of } \\
\text { Institutionalized } \\
\text { Politeness }\end{array}$ & $\begin{array}{l}\text { Offer a favor } \\
\text { politely. }\end{array}$ \\
\hline
\end{tabular}

In this dialogue, there is found idiomatic expression "May I help you?" which is a traditional polite expression. From the context, the meaning of this idiom is "offer a favor politely". from the dialogue said by character Brenda May I help you? It is shown that Brenda offering help to George politely. The sentence "May I help you refers to Institutionalize politeness because it 
shows conventional polite expression. (Farlex, 2019).

\section{Idioms of Institutionalized Detachment or Indirectness}

There is found only one idiom in idioms of institutionalized detachment or indirectness, for example:

\begin{tabular}{|c|c|c|c|c|}
\hline $\begin{array}{c}\text { Dialogue } \\
\text { using } \\
\text { Idiomatic } \\
\text { Expression }\end{array}$ & Duration & $\begin{array}{l}\text { Idiomatic } \\
\text { Expression }\end{array}$ & $\begin{array}{l}\text { Kinds of } \\
\text { Idiomatic } \\
\text { Expression }\end{array}$ & Meaning \\
\hline $\begin{array}{l}\text { The } \\
\text { Professor: } \\
\text { It's not as } \\
\text { effective } \\
\text { as the maze, } \\
\text { but it seems to } \\
\text { be working. } \\
\text { Ava Paige: } \\
\text { It's promising. } \\
\text { But we'll need } \\
\text { a larger } \\
\text { sample } \\
\text { to work with. }\end{array}$ & $\begin{array}{l}\text { 00:23:56,760 --> } \\
00: 24: 05,500\end{array}$ & $\begin{array}{l}\text { It seems to be } \\
\text { working }\end{array}$ & $\begin{array}{l}\text { Idioms of } \\
\text { Institutionalized } \\
\text { Detachment or } \\
\text { Indirectness }\end{array}$ & $\begin{array}{l}\text { To progress throug } \\
\text { something complicated. }\end{array}$ \\
\hline
\end{tabular}

In this dialogue, there is found idiomatic expression "It seems to be working" which is indicating detachment. From the context, the meaning of this idiom is "to progress through something complicated". from the dialogue of the character The Professor, it seems to be working, it shown that the professor assured Ava that the progress of collecting the sample was progressing even though it was complicated to do. The sentence "seems to be working" is belong to Institutionalized Detachment or Indirectness, because it contained conventional expressions indicating detachment or indirectness. The word "seems to be working" indicated progress of something complicated. (Farlex, 2019).

\section{Idioms of Institutionalized Greeting}

There are found 4 idioms in idioms of institutionalized greeting and there are some of them with the same idiomatic expression but in different duration, for example:

\begin{tabular}{|c|c|c|c|c|}
\hline $\begin{array}{l}\text { Dialogue using } \\
\text { Idiomatic } \\
\text { Expression }\end{array}$ & Duratiou & $\begin{array}{l}\text { Idiomatic } \\
\text { Expression }\end{array}$ & $\begin{array}{l}\text { Kinds of } \\
\text { Idiomatic } \\
\text { Expression }\end{array}$ & Meaning \\
\hline $\begin{array}{l}\text { Thomas: Newrt, } \\
\text { how you doing? } \\
\text { Newt: Don't } \\
\text { rush me. } \\
\text { Thomas: Shit! } \\
\text { Newt, get up } \\
\text { here. }\end{array}$ & $\begin{array}{l}\cdot 00: 09: 05,000-> \\
00: 09: 23,450 \\
\cdot 01: 13: 31,960-> \\
01: 13: 34,039\end{array}$ & $\begin{array}{l}\text { How you } \\
\text { doing? }\end{array}$ & $\begin{array}{l}\text { Idioms of } \\
\text { Institutionalized } \\
\text { Greeting }\end{array}$ & $\begin{array}{l}\text { A standard greeting inquiry. (The } \\
\text { entry without is is informal and } \\
\text { usually pronounced "How ya } \\
\text { doin?") }\end{array}$ \\
\hline
\end{tabular}

In this dialogue, there is found idiomatic expression "How you doing?" which is a conventional expression of greeting. From the context, the meaning of this idiom is "a standard greeting inquiry (the entry without 'are' is informal and usually pronounced 'how ya doin?" based on Dictionary of American Idioms and Phrasal Verbs. From the dialogue said by Thomas Newt, how you doing? It shown that Thomas showed his greeting to his best friend in the movie, not only to ask Newt's Day, but also his condition and mind. The sentence "how you doing?" it belongs to Idioms of Institutionalized greeting, by means it contained conventional expressions of standard greeting with formal or informal way. (Spears, 2006).

\section{Familiar Quotations as Idioms}

There are 2 idioms in familiar quotations as idioms, for example:

\begin{tabular}{|c|c|c|c|c|}
\hline $\begin{array}{l}\text { Dialogue using Idiomatic } \\
\text { Expression }\end{array}$ & Duration & $\begin{array}{l}\text { Idiomatic } \\
\text { Expression }\end{array}$ & $\begin{array}{l}\text { Kinds of } \\
\text { Idiomatic } \\
\text { Expression }\end{array}$ & Meaning \\
\hline $\begin{array}{l}\text { Minho: Why you helping us, } \\
\text { Gally? I put a spear through } \\
\text { your chest. } \\
\text { Gallv: Yeah. Nobody's } \\
\text { perfect, man. }\end{array}$ & $\begin{array}{l}\text { 01:36:00,080 } \\
\overrightarrow{-} \\
01: 36: 10,259\end{array}$ & $\begin{array}{c}\text { Nobody's } \\
\text { perfect }\end{array}$ & $\begin{array}{l}\text { Familiar } \\
\text { Quotations as } \\
\text { Idioms }\end{array}$ & $\begin{array}{l}\text { To say that } \\
\text { everyone makes } \\
\text { mistake. }\end{array}$ \\
\hline
\end{tabular}

In this dialogue, there is found idiomatic expression "Nobody's perfect", from the context, the meaning of this idiom is "to say that everyone makes mistake". from the dialogue said by Gally Nobody's perfect, it shown that everybody includes him do mistakes. This sentence is belonging to familiar quotations as idioms, because it indicated quotations from well-known figures or source. The sentence did not show who said this, but Gally as a main character in the movie interpreted as support for this model of idiomatic which suggest others to be fine to make mistake. (Merriam Webster's Unabridged Dictionary, 2011).

The meaning of symbol contained on idiomatic expressions revealed in the dialogue spoken by the characters of The Maze Runner: The Death Cure movie

The researchers found 26 idiomatic expressions that containing a language symbol from 59 idiomatic expressions which were classified based on Makkai's theory. For 
example:

\begin{tabular}{|c|c|c|c|}
\hline $\begin{array}{c}\text { Dialogue using Idiomatic } \\
\text { Expression }\end{array}$ & Duration & \begin{tabular}{l|l} 
Idiomatic \\
Expression \\
\end{tabular} & Semiotic Analysis of Symbol \\
\hline $\begin{array}{l}\text { Ava: It's promising. But we'll need a } \\
\text { larger sample to work with. } \\
\text { The Professor: All right. Carry on. }\end{array}$ & $\begin{array}{l}\text { 00:24:00,760 ->> } \\
\text { 00:24:10,695 }\end{array}$ & Carry on & Carry \\
\hline $\begin{array}{l}\text { Thomas: I don't think we have much } \\
\text { of a choice. } \\
\text { Newt: All right. I get shotgun. } \\
\text { Frypan: Well, here we go. } \\
\text { Newt: Yeah, just take it mice and slow. }\end{array}$ & $\begin{array}{l}00: 25: 56,040 \ldots>> \\
00: 27: 04,374\end{array}$ & $\begin{array}{c}\text { Nice and } \\
\text { slow }\end{array}$ & Nice \\
\hline $\begin{array}{c}\text { Thomas: Hey, Brenda, you got } \\
\text { company! } \\
\text { Brenda: Go, go, go! } \\
\text { The company: Open fire. } \\
\text { George: Watch out! Holy shit! }\end{array}$ & $\begin{array}{c}00: 04: 52,360 \quad- \\
>00: 05: 16,450 \\
\cdot 01: 39: 31,800 \quad-.> \\
01: 39: 33,857 \\
\cdot 01: 39: 31,800 \quad .- \\
01: 39: 33,857 \\
\end{array}$ & Open fire & Fire \\
\hline $\begin{array}{l}\text { Minho: You sure about this? } \\
\text { Thomas: Not really. } \\
\text { Minho: Nice pep talk. } \\
\text { Newt; Yeah, we're all } \\
\text { bloody inspired. }\end{array}$ & $\begin{array}{l}01: 28: 04,160-> \\
01: 28: 11,651\end{array}$ & Pep talk & Pep \\
\hline
\end{tabular}

\section{- Carry}

Based on semiotic analysis of symbol "Carry" in the idiomatic expression "Carry on" has denotative meaning to hold or support while moving. (American Heritage, 2020) which is the actual meaning or primary description and connotative meaning to keep doing as before, continue. (Makkai, Boatner, $\&$ Gates, 2004) which is the cultural meaning that connected to a symbol.

- Nice

Based on semiotic analysis of symbol "Nice" in the idiomatic expression "Nice and slow" has denotative meaning as a good character, reputation, and respectable (American Heritage, 2020) which is the actual meaning or primary description and connotative meaning as to go or act slowly, carefully, and gently (Farlex, 2019) which is the cultural meaning that connected to a symbol.

- Fire

Based on semiotic analysis of symbol "Fire" in the idiomatic expression "Open fire" and "Hold fire" has the same denotative and connotative meaning. A symbol "Fire" has denotative meaning as something cause to burn, ignite or set fire (American Heritage, 2020) which is the actual meaning or primary description and connotative meaning as a shoot of weapon (American Heritage, 2020) which is the cultural meaning that connected to a symbol.

- Pep
Based on semiotic analysis of symbol "Pep" in the idiomatic expression "Pep talk" has denotative meaning as energy (Farlex, 2019) which is the actual meaning or primary description and connotative meaning as a speech that makes people feel good so they will try harder and not give up (Makkai, Boatner, \& Gates, 2004) which is the cultural meaning that connected to a symbol.

\section{The implication of semiotic analysis of idiomatic expressions found in The Maze Runner: The Death Cure movie to English language skills}

The researchers have conducted some questions according some theories related with the implication of studying idiomatic expression and also semiotic analysis which is conducted in chapter two. The questions are: (1) What are the importance of teaching idiomatic expressions in English class? Is it important to teach idiomatic expressions in English class? (2) What are the movie is the right media to study about idiomatic expression? If so, how could? If no, what is the right media to study about idiomatic expression?, (3) Why semiotic theory of Roland Barthes which explains about denotative and connotative meaning of language symbol have to be studied in English class?, (4) How do you teach a semiotic analysis of idiomatic expressions in English class?, (5) What is the implication of semiotic analysis of idiomatic expression found in movie on English class?

Based on five questions that have been answered, it can be concluded that the implication of semiotic analysis of idiomatic expressions found in movie to English language are: (1) The students could look like an English native speaker, (2) Increase a new vocabulary, (3) More fluently in communication using English, (4) Make the students aware a different culture in language learning, (5) Make the students more meaningful and understandable 


\section{CONCLUSION}

There are 59 idiom expressions divided into lexemic and sememic idioms found in The Maze Runner: The Death Cure movie by Wess Ball. From lexemic idiom found 37 phrasal verbs; 2 irreversible binomials; 10 phrasal compounds; and 1 incorporating verb. From the sememic idiom found 2 idioms of politeness; 1 idiom of detachment; 4 idioms of greeting; and 2 famous quotations idioms.

There are 26 symbols from 59 idiom expressions in the movie such as hang on, hang out, watch, give, wiping, start, carry, break, rise, count, shut off, shut up, nice, over and over, crowd, the edge off, fire, a seat, hit the Glade, hit the light, cover, shy, and pep. The implication on English language are make students more fluent in English and look like native speakers, add new vocabulary, make students aware of cultural differences in language, and know more about meaning.

More often to teach and learn idiomatic expressions based on some experts using a movie or others media such as books, ebooks, YouTube channel, and application. However, the teacher should connect with the syllabus or RPS. The researchers hope to other researchers who have the similar research could analyze the movie that contains idioms which includes of sememic idiom or other movie to know the differences and bring the research to the higher level of understanding.

\section{REFERENCES}

Abuarqoub, I. A. (2019). The Article: Language Barriers to Effective Communication, vol.24 esp.6, pp.6477,2019. Universidad del Zulia

Ambrose, J. (2003). Why Idioms Are Important for English Language Learners. Mikolaiv State Pedagogical University.

American, H. (2020). Dictionary of The English Language, Fifth Edition. USA: Summit Park Prints Houghton Mifflin Harcourt.

Boers, F. (2008). Language Awareness: Understanding Idioms at macmillandictionaries.com. Retrieved from(http://www.macmillaandictionaries. com/MEDMagazine//February/2008/49-
LA-Idioms-Print.htm).

Cowie AP, Mackin R, McCgaig IR. (1983). Oxford Dictionary of English Idioms. Volume 2. Oxford: Oxford University Press.

Barthes, R. (1968). Elements of Semiology $1^{\text {st }}$ Edition. New York: Hilland Wang.

Farlex. (2019). The Free Dictionary. Pennsylvania: Farlex, Inc.

Gairns, R. \& Redman, S. (2011). Idioms and Phrasal Verbs. New York: Oxford University Press.

Gay, L. R., Mills, G. E. \& Airasian, P. (2012). Educational research: competencies for analysis and applications (Tenth edition). United States: Pearson Education, Inc.

Makkai, A. (1972). Idiom Structure in English. Mouton: The Hague.

Makkai, A. \& Boatner, M. T. \& Gates, J.E. (2004). A Dictionary of American Idioms (Fourth edition). New York: Barron's Educational Series, Inc.

Merriam, S. B. (1998). Qualitative Research and Case Study Applications in Education. San Francisco: Jossey-Bass.

Merriam, G. \& Merriam, C. (2011). MerriamWebster's Unabridged Dictionary. USA: Merriam-Webster, Inc.

Palmer, F. R. (1976). Semantics: A New Outline. Cambridge: Cambridge University Press.

Polit, D.F. \& Beck, C.T. (2014). Essentials of Nursing Research: Appraising Evidence for Nursing Practice $\left(8^{\text {th }}\right.$ ed.). Philadelphia: Wolters Klumer.

Purnamasari, A. V. (2019). Teaching English Idioms to EFL Students Through Songs. Pengembangan Pendidikan, vol.6. no. 2, hal 156-164, Desember 2009.

Ovando J, \& Collier V. (1985). Billingual and ESL Classrooms: Teaching in Multicultural Contexts. New York: McGraw-Hill.

Rizq, W. (2015). Teaching English Idioms to L2 Learners: ESL Teachers' Perspective. St. Cloud State University.

Spears, R. A. (2006). Dictionary of American Idioms and Phrasal Verb. USA: McGrawHill.

Spolsky, B. (1995). Language Arts \& Diciplines. Berlin/New York: Mouton de Gruyter.

Thyab, R. A. (2016). The Necessity of Idiomatic Expressions to English Language Learners. International Journal of English and Literature. Vo.7 (7), pp. 106-111, July 2016. Iraq:

Ministry of Higher Education and Scientific 
Dialectical Literature and Education Journal (DLEJ)

Volume 6, Issue 1, June 2021
p-ISSN 2548-6926, e-ISSN 2714-996X

https://dlejpancasakti.ac.id/index.php/dlejpancasakti

Research, College of Education for Women, Tikrit University.

Todorov, T. (1984). Theories of The Symbol, Trans. New York: University Press. 